Cite this: RSC Adv., 2014, 4, 26569

Received 17th April 2014 Accepted 29th May 2014

DOI: $10.1039 / c 4 r a 03482 a$

www.rsc.org/advances

\section{Palladium(II) complexes with chiral organoantimony(III) ligands. Solution behaviour and solid state structures $\$$}

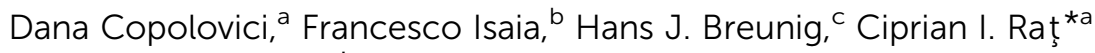 \\ and Cristian Silvestru*a
}

The chiral compound (2- $\left.\mathrm{Me}_{2} \mathrm{NCH}_{2} \mathrm{C}_{6} \mathrm{H}_{4}\right) \mathrm{PhSbCl}$ (1) was obtained from (2- $\mathrm{Me}_{2} \mathrm{NCH}_{2} \mathrm{C}_{6} \mathrm{H}_{4}$ ) $\mathrm{Li}$ and $\mathrm{PhSbCl}$ in 1:1 molar ratio, while $\left(2-\mathrm{Me}_{2} \mathrm{NCH}_{2} \mathrm{C}_{6} \mathrm{H}_{4}\right) \mathrm{Mes}_{2} \mathrm{Sb}$ (2) was prepared from $\left(2-\mathrm{Me}_{2} \mathrm{NCH}_{2} \mathrm{C}_{6} \mathrm{H}_{4}\right) \mathrm{SbCl}_{2}$ and $\mathrm{Mes} \mathrm{MgBr}$ in $1: 2$ molar ratio. The compounds 1 and 2 were used to obtain the $\mathrm{Pd}(॥) /$ stibine complexes: $\left.\left[\mathrm{Me}_{2} \mathrm{NHCH}_{2} \mathrm{C}_{6} \mathrm{H}_{5}\right]^{+}\left[\mathrm{PdCl} 33 \mathrm{SbCl}(\mathrm{Ph})\left(\mathrm{C}_{6} \mathrm{H}_{4} \mathrm{CH}_{2} \mathrm{NMe}_{2}-2\right)-\mathrm{Sb}\right\}\right]^{-}$(3) and $\left[\mathrm{PdCl}_{2}\left\{\mathrm{SbMes}_{2}\left(\mathrm{C}_{6} \mathrm{H}_{4} \mathrm{CH}_{2} \mathrm{NMe}_{2}-2\right)-\right.\right.$ $N, S b\}$ ] (4). All the compounds were characterized by multinuclear NMR spectroscopy in solution, elemental analysis, mass spectrometry and single-crystal X-ray diffraction studies. In compounds 1-3 the coordination geometry around the antimony atom is pseudo-trigonal bipyramidal, while in compound 4 a tetrahedral geometry around the antimony atom is observed. Theoretical calculations at the DFT level on compounds 1-4 were used in order to gain insight into the nature of the coordinative bonds.

\section{Introduction}

In recent years, stibines have been synthesized, characterized in detail and used as ligands to develop the coordination chemistry of antimony. ${ }^{\mathbf{1 - 1 3}}$ Methods of preparation and the physical and chemical properties of the complexes which contain organostibines as ligands have been investigated in order to compare their similarities and differences with those of the lighter analogues, to stabilize air-sensitive stibines, or to separate the diastereomeric mixture of some chiral stibines via their palladium complexes. ${ }^{\mathbf{1 4 - 1 7}}$

Examples of palladium(II) complexes which contain stibines as ligands are well known. Most of the complexes $\left[\mathrm{PdX}_{2}\left(\mathrm{SbR}_{3}\right)_{2}\right]$

\footnotetext{
${ }^{a}$ Departamentul de Chimie, Centrul de Chimie Supramoleculară Organică şi Organometalică (CCSOOM), Facultatea de Chimie și Inginerie Chimică, Universitatea Babeș-Bolyai, RO-400028, Cluj-Napoca, Romania. E-mail: ciprian. rat@ubbcluj.ro; cristian.silvestru@ubbcluj.ro; Fax: +40-264-590818; Tel: +40-264593833

${ }^{b}$ Dipartimento di Scienze Chimiche e Geologiche, Università degli Studi di Cagliari, S.S. 554 Bivio per Sestu, 09042 Monserrato (CA), Italy.E-mail: isaia@unica.it ${ }^{c}$ Institut für Anorganische und Physikalische Chemie, Universität Bremen, 28334 Bremen, Germany.E-mail: hbreunig@uni-bremen.de

$\dagger$ Electronic supplementary information (ESI) available: X-ray crystallographic data in CIF format for 1-4; figures representing the optical isomers as well as the supramolecular architectures and intermolecular contacts in the crystals of these compounds; representations of calculated vs. determined structures; comparison between experimental and calculated of bond lengths and angles of 1-4 and the Cartesian coordinates of the optimized structures. CCDC 978906 (1), 978907 (2), 978908 (3) and 978909 (4). For ESI and crystallographic data in CIF or other electronic format see DOI: 10.1039/c4ra03482a

\$ Dedicated to Professor Marius Andruh (University of Bucharest, Romania) on the occasion of his 60th birthday.
}

( $\mathrm{X}=\mathrm{Cl}, \mathrm{Br}, \mathrm{I}$, and $\mathrm{R}={ }^{\mathrm{i}} \mathrm{Pr} ;{ }^{18} \mathrm{X}=\mathrm{Cl}, \mathrm{Br}$, and $\mathrm{R}=o$-tolyl $;^{19} \mathrm{X}=\mathrm{I}$, and $\mathrm{R}=\mathrm{Ph})^{20}$ were synthesised from $\left[\mathrm{PdX}_{2}(\mathrm{COD})\right]$ (COD = cycloocta-l,5-diene) or $\mathrm{PdX}_{2}(\mathrm{X}=\mathrm{Cl}, \mathrm{Br}, \mathrm{I})$ and triorganoantimony, respectively, and only trans isomers have been obtained. The reaction of $\mathrm{Ph}_{3} \mathrm{Sb}$ with $\left[\mathrm{PdX}_{2}(\mathrm{COD})\right](\mathrm{X}=\mathrm{Cl}, \mathrm{Br})$ afforded trans-[ $\left.\mathrm{PdX}(\mathrm{Ph})\left(\mathrm{SbPh}_{3}\right)_{2}\right]$ as a result of antimony-carbon bond cleavage. ${ }^{21}$ The reaction of $\mathrm{Na}_{2} \mathrm{PdCl}_{4}$ with $\mathrm{Ph}_{3} \mathrm{Sb}$ gave a mixture of cis- $\left[\mathrm{PdCl}_{2}\left(\mathrm{SbPh}_{3}\right)_{2}\right](40 \%)$ and trans- $\left[\mathrm{PdCl}(\mathrm{Ph})\left(\mathrm{SbPh}_{3}\right)_{2}\right]$, while the reaction of $\mathrm{PdBr}_{2}$ with $\mathrm{Ph}_{3} \mathrm{Sb}$ afforded only cis$\left[\mathrm{PdBr}_{2}\left(\mathrm{SbPh}_{3}\right)_{2}\right] .{ }^{21}$ The treatment of $\mathrm{Ph}_{3} \mathrm{Sb}$ with $[\mathrm{Pd}(\mu$ $\left.\mathrm{Cl})\left(\mathrm{C}_{6} \mathrm{H}_{4} \mathrm{CH}_{2} \mathrm{NMe}_{2}-2\right)\right]_{2}$ in $2: 1$ and $4: 1$ molar ratio gave the expected cyclometallated complexes: $\left[\mathrm{PdCl}\left(\mathrm{C}_{6} \mathrm{H}_{4} \mathrm{CH}_{2} \mathrm{NMe}_{2}\right.\right.$ $\left.2)\left(\mathrm{SbPh}_{3}\right)\right]$ and $\left[\mathrm{PdCl}\left(\mathrm{C}_{6} \mathrm{H}_{4} \mathrm{CH}_{2} \mathrm{NMe}_{2}-2\right)\left(\mathrm{SbPh}_{3}\right)_{2}\right]{ }^{22}$ The synthesis and structural characterization of some palladiumdistibine complexes as $\left[\mathrm{PdCl}(\mathrm{Ph})\left(\mu-\mathrm{Ph}_{2} \mathrm{SbCH}_{2} \mathrm{SbPh}_{2}\right)\right]_{2}{ }^{23}$ $\left[\mathrm{PdCl}_{2}\left\{\mathrm{C}_{6} \mathrm{H}_{4}\left(\mathrm{CH}_{2} \mathrm{SbMe}_{2}\right)_{2}-1,2\right\}\right],{ }^{11}$ or $\left[\mathrm{PdCl}\left\{\mathrm{C}_{6} \mathrm{H}_{4} \mathrm{CH}(\mathrm{Me}) \mathrm{NMe}_{2}-\right.\right.$ $2\}(\mathrm{BINASb}-\mathrm{Sb})] \quad$ (BINASb $=2,2^{\prime}$-bis[diphenylstibino]-1,1'binaphthyl) ${ }^{24}$ were also reported.

The racemic mixtures of ( \pm )-1-phenyl-2-trimethylsilylstibindole, ${ }^{17} \quad( \pm)$-2, $2^{\prime}$-bis[di( $p$-tolyl)stibino]-1,1'-binaphthyl, ${ }^{\mathbf{1 6}}$ $( \pm)$-2-(S)-(1-dimethylaminoethyl)phenyl(1-naphthyl)( $p$-tolyl)stibines, ${ }^{15} \quad( \pm)$-(4,4-dimethyl)-\{2-[(1-naphthyl)( $p$-tolyl)stibino]phenyl 1,3 -oxazoline, ${ }^{\mathbf{1 4}}$ or $( \pm)$-(2-methoxymethylphenyl)(1-naphthyl)( $p$-tolyl)stibine ${ }^{\mathbf{1 4}}$ were separated via chromatography by the reaction with $\mathrm{di}-\mu$-chloro-bis $[(S)-2-\{1$-(dimethylamino)ethyl $\}$ phenyl- $C, N]$ dipalladium(II), ${ }^{16,17} \quad \mathrm{di}-\mu$-chloro-bis[2$\{($ dimethylamino)methyl $\}$ phenyl- $C, N]$ dipalladium(II),${ }^{15}$ or $\mathrm{di}-\mu$ chloro-bis $[(S)-2-\{1$-(dimethylamino)ethyl\}naphthyl- $C, N]$ dipalladium(II), respectively. ${ }^{\mathbf{1 4}}$ The structure of the stibine diastereoisomers and their palladium complexes in solution was 
investigated by NMR spectroscopy and the solid state structure of several isomers was determined by X-ray diffraction studies.

We have previously published the synthesis and structural characterization in solution of the organoantimony(III) derivatives (2- $\left.\mathrm{Me}_{2} \mathrm{NCH}_{2} \mathrm{C}_{6} \mathrm{H}_{4}\right) \mathrm{PhSbCl}$ (1) and $\left(2-\mathrm{Me}_{2} \mathrm{NCH}_{2} \mathrm{C}_{6} \mathrm{H}_{4}\right)$ $\mathrm{Mes}_{2} \mathrm{Sb}(2) .{ }^{25}$ We report here the solid state structures of 1 and 2 as well as the syntheses and structural characterization of their complexes $\left[\mathrm{Me}_{2} \mathrm{NHCH}_{2} \mathrm{C}_{6} \mathrm{H}_{5}\right]^{+}\left[\mathrm{PdCl}_{3}\left\{\mathrm{SbCl}(\mathrm{Ph})\left(\mathrm{C}_{6} \mathrm{H}_{4} \mathrm{CH}_{2} \mathrm{NMe}_{2}-\right.\right.\right.$ 2)-Sb\}] $]^{-}$(3) and $\left[\mathrm{PdCl}_{2}\left\{\mathrm{SbMes}_{2}\left(\mathrm{C}_{6} \mathrm{H}_{4} \mathrm{CH}_{2} \mathrm{NMe}_{2}-2\right)-N, S b\right\}\right]$ (4).

\section{Results and discussion}

\section{Synthesis}

The compounds (2- $\left.\mathrm{Me}_{2} \mathrm{NCH}_{2} \mathrm{C}_{6} \mathrm{H}_{4}\right) \mathrm{PhSbCl}$ (1) and (2$\left.\mathrm{Me}_{2} \mathrm{NCH}_{2} \mathrm{C}_{6} \mathrm{H}_{4}\right) \mathrm{Mes}_{2} \mathrm{Sb}(2)$ were obtained according to literature methods by the reaction of $\mathrm{PhSbCl}_{2}$ with $\left(2-\mathrm{Me}_{2} \mathrm{NCH}_{2} \mathrm{C}_{6} \mathrm{H}_{4}\right) \mathrm{Li}$ in $1: 1$ molar ratio or by the reaction of $\left(2-\mathrm{Me}_{2} \mathrm{NCH}_{2} \mathrm{C}_{6} \mathrm{H}_{4}\right) \mathrm{SbCl}_{2}$ with two equivalents of $\mathrm{MesMgBr}$, respectively. ${ }^{25}$ The ionic complex $\left[\mathrm{Me}_{2} \mathrm{NHCH}_{2} \mathrm{C}_{6} \mathrm{H}_{5}\right]^{+}\left[\mathrm{PdCl}_{3}\left\{\mathrm{SbCl}(\mathrm{Ph})\left(\mathrm{C}_{6} \mathrm{H}_{4} \mathrm{CH}_{2} \mathrm{NMe}_{2}-2\right)-\right.\right.$ $S b\}]^{-}$(3) was obtained by the reaction of 1 with $\left[\mathrm{PdCl}_{2}(\mathrm{NCMe})_{2}\right]$ in $1: 1$ or in 2:1 molar ratio, at room temperature, or by reacting 1 and $\mathrm{PdCl}_{2}$ in $\mathrm{CH}_{2} \mathrm{Cl}_{2}$, at reflux temperature for $4 \mathrm{~h}$ (see Scheme 1). The same compound was also obtained from $\mathbf{1}$, $\left[\mathrm{PdCl}_{2}(\mathrm{NCMe})_{2}\right]$ and $\left[2-\mathrm{Me}_{2} \mathrm{NHCH}_{2} \mathrm{C}_{6} \mathrm{H}_{5}\right]^{+} \mathrm{Cl}^{-}$. It was isolated as a brown, air-stable compound, soluble in $\mathrm{CH}_{2} \mathrm{Cl}_{2}$ and $\mathrm{CHCl}_{3}$.

Reaction of 2 with $\left[\mathrm{PdCl}_{2}(\mathrm{COD})\right]$ in $\mathrm{CHCl}_{3}$ at reflux temperature afforded the neutral complex $\left[\mathrm{PdCl}_{2}\left\{\mathrm{SbMes}_{2}\left(\mathrm{C}_{6} \mathrm{H}_{4} \mathrm{CH}_{2}\right.\right.\right.$ $\left.\left.\left.\mathrm{NMe}_{2}-2\right)-N, S b\right\}\right]$ (4) (Scheme 2) as a yellow, air stable solid, soluble in $\mathrm{CH}_{2} \mathrm{Cl}_{2}, \mathrm{CHCl}_{3}$, and DMSO, but poorly soluble in benzene.

Single crystals suitable for X-ray diffraction studies were obtained via slow diffusion of hexane into a solution of $\mathbf{1}$ in EtOH, of 3 in $\mathrm{CH}_{2} \mathrm{Cl}_{2}$ and of 4 in $\mathrm{CHCl}_{3}$. Slow evaporation of the solvent from a hexane solution afforded single crystals of 2 .

\section{Solid state and solution behaviour}

$\mathrm{X}$-ray diffraction studies revealed that $\mathbf{1}$ crystallizes as racemate [1:1 mixture of $\left(R_{\mathrm{N}}, A_{\mathrm{Sb}}\right)$ and $\left(S_{\mathrm{N}}, C_{\mathrm{Sb}}\right)$ isomers] (see ESI, Fig. $\mathrm{S} 1 \dagger){ }^{25-27}$ The molecular structure of $\left(R_{\mathrm{N}}, A_{\mathrm{Sb}}\right)-(2-$ $\left.\mathrm{Me}_{2} \mathrm{NCH}_{2} \mathrm{C}_{6} \mathrm{H}_{4}\right) \mathrm{PhSbCl}$ is shown in Fig. 1. Selected bond distances and angles are given in Table 1.

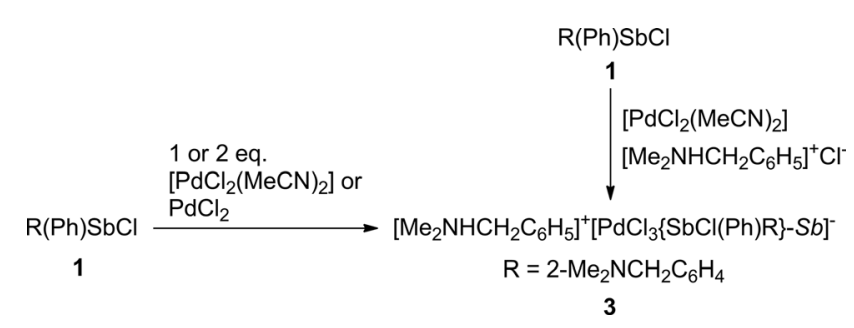

Scheme 1 Preparation of complex 3.

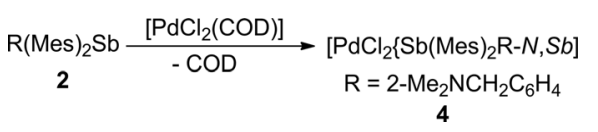

Scheme 2 Preparation of complex 4.
The molecular unit features a metal centre strongly coordinated by the nitrogen of the pendant $\operatorname{arm}[\mathrm{Sb}(1)-\mathrm{N}(1) 2.452(2) \AA]$ trans to $\mathrm{Sb}-\mathrm{Cl}$ bond $\left[\mathrm{N}(1)-\mathrm{Sb}(1)-\mathrm{Cl}(1) 165.05(7)^{\circ}\right]$. The $\mathrm{Sb}-\mathrm{N}$ distance lies between the sums of the covalent $\left[\Sigma r_{\text {cov }}(\mathrm{Sb}, \mathrm{N}) 2.11\right.$ $\AA]$ and van der Waals radii $\left[\Sigma r_{\mathrm{vdw}}(\mathrm{Sb}, \mathrm{N}) 3.74 \AA\right]$ of antimony and nitrogen atoms. ${ }^{28}$

The antimony centre is in a distorted pseudo-trigonal bipyramidal environment $[(C, N) \mathrm{CSbCl}$ core $]$. The deviations of the bond angles at the metal atom from the ideal values are mainly due to the constraints imposed by the small bite of the $C, N$-bidentate ligand (Table 1). Two carbon atoms and the lone pair of electrons occupy the equatorial sites, while the chlorine and the nitrogen atoms are placed in the axial positions. The antimony-chlorine bond length in 1 [Sb(1)- $\mathrm{Cl}(1) 2.5111(9) \AA]$ is similar to that found in $\left(2-\mathrm{Me}_{2} \mathrm{NCH}_{2} \mathrm{C}_{6} \mathrm{H}_{4}\right)_{2} \mathrm{SbCl}[\mathrm{Sb}-\mathrm{Cl} 2.579(9)$ $\AA],{ }^{29}$ and considerably longer than observed for $\mathrm{Ph}_{2} \mathrm{SbCl}$ [Sb-Cl 2.409(1) $\AA$ ] ${ }^{30}$ a behaviour consistent with the $\sigma^{*}$-orbital bonding model. ${ }^{29,31}$

A closer check of the crystal structure of 1 revealed several hydrogen bonding interactions resulting in a supramolecular architecture (see ESI, Fig. S2 $\dagger$ ). Within a molecule of $\left(2-\mathrm{Me}_{2} \mathrm{NCH}_{2} \mathrm{C}_{6} \mathrm{H}_{4}\right) \mathrm{PhSbCl}$ there is a short intramolecular $\mathrm{Cl} \cdots \mathrm{H}$ contact $[\mathrm{Cl}(1) \cdots \mathrm{H}(6) 2.74 \AA$; $c f$. sum of the respective van der Waals radii is $\Sigma r_{\mathrm{vdw}}(\mathrm{Cl}, \mathrm{H})$ ca. $\left.3.01 \AA\right] .{ }^{28}$ The chlorine atom is also involved in an intermolecular interaction with a hydrogen atom

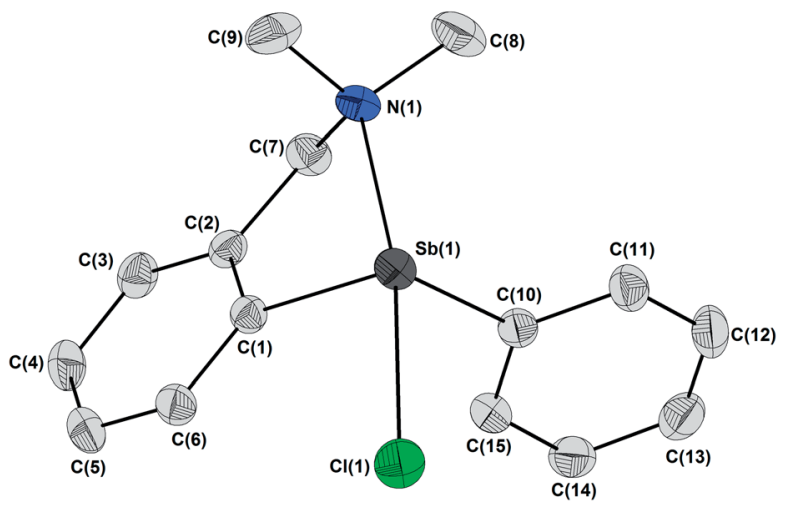

Fig. 1 Displacement ellipsoid representation (25\% probability level) of $\left(R_{N}, A_{\mathrm{Sb}}\right)-1$ isomer. The hydrogen atoms were omitted for clarity.

Table 1 Selected interatomic distances $(\AA)$ and angles $\left(^{\circ}\right)$ in 1 and 2

\begin{tabular}{llll}
\hline 1 & \multicolumn{3}{c}{} \\
\hline $\mathrm{Sb}(1)-\mathrm{C}(1)$ & $2.147(3)$ & $\mathrm{Sb}(1)-\mathrm{C}(1)$ & $2.172(4)$ \\
$\mathrm{Sb}(1)-\mathrm{C}(10)$ & $2.153(3)$ & $\mathrm{Sb}(1)-\mathrm{C}(10)$ & $2.203(4)$ \\
$\mathrm{Sb}(1)-\mathrm{Cl}(1)$ & $2.5111(9)$ & $\mathrm{Sb}(1)-\mathrm{C}(19)$ & $2.178(4)$ \\
$\mathrm{Sb}(1)-\mathrm{N}(1)$ & $2.452(2)$ & $\mathrm{Sb}(1)-\mathrm{N}(1)$ & $3.052(3)$ \\
& & & \\
$\mathrm{N}(1)-\mathrm{Sb}(1)-\mathrm{Cl}(1)$ & $165.05(7)$ & $\mathrm{N}(1)-\mathrm{Sb}(1)-\mathrm{C}(10)$ & $162.40(11)$ \\
$\mathrm{C}(1)-\mathrm{Sb}(1)-\mathrm{C}(10)$ & $94.98(11)$ & $\mathrm{C}(1)-\mathrm{Sb}(1)-\mathrm{C}(19)$ & $100.95(14)$ \\
$\mathrm{N}(1)-\mathrm{Sb}(1)-\mathrm{C}(1)$ & $74.59(10)$ & $\mathrm{N}(1)-\mathrm{Sb}(1)-\mathrm{C}(1)$ & $67.54(11)$ \\
$\mathrm{N}(1)-\mathrm{Sb}(1)-\mathrm{C}(10)$ & $88.78(10)$ & $\mathrm{N}(1)-\mathrm{Sb}(1)-\mathrm{C}(19)$ & $73.46(11)$ \\
$\mathrm{Cl}(1)-\mathrm{Sb}(1)-\mathrm{C}(1)$ & $91.00(8)$ & $\mathrm{C}(1)-\mathrm{Sb}(1)-\mathrm{C}(10)$ & $96.06(14)$ \\
$\mathrm{Cl}(1)-\mathrm{Sb}(1)-\mathrm{C}(10)$ & $88.54(8)$ & $\mathrm{C}(19)-\mathrm{Sb}(1)-\mathrm{C}(10)$ & $104.88(14)$
\end{tabular}


of the phenyl group $\left[\mathrm{Cl}(1) \cdots \mathrm{H}\left(12^{\prime \prime}\right) 2.80 \AA\right]$ resulting in helicoidal chains of same isomers. Parallel chains are connected by intermolecular $\mathrm{C}-\mathrm{H} \cdots \mathrm{Cg}$ contacts between $\left(R_{\mathrm{N}}, A_{\mathrm{Sb}}\right)$ and $\left(S_{\mathrm{N}}, C_{\mathrm{Sb}}\right)$ isomers, consistent with $\pi$ interactions between hydrogen atoms of the methylene group and the aromatic phenyl ring attached to the metal (i.e. $\mathrm{H} \cdots \mathrm{Ph}$ centroid contacts shorter than 3.1 A, with an angle $\gamma$ between the normal to the aromatic ring and the line defined by the $\mathrm{H}$ atom and $\mathrm{Ph}$ centroid smaller than $\left.30^{\circ}\right):{ }^{32} \mathrm{C}(7)-\mathrm{H}(7 \mathrm{~B}) \cdots \mathrm{Cg}\left(3^{\mathrm{i}}\right) 2.97 \AA, \gamma=15.1^{\circ}$ (see ESI, Table $\mathrm{S} 1 \dagger)$. Layers are thus formed, with $\left(R_{\mathrm{N}}, A_{\mathrm{Sb}}\right) /\left(S_{\mathrm{N}}, C_{\mathrm{Sb}}\right)$ dimer units connected to other four neighbouring dimers through $\mathrm{Cl} \cdots \mathrm{H}$ interactions (see ESI, Fig. S3†).

The stibine 2 crystallized as pairs of $\left(R_{\mathrm{N}}, C_{\mathrm{Sb}}\right)$ and $\left(S_{\mathrm{N}}, A_{\mathrm{Sb}}\right)$ isomers (see ESI, Fig. $\mathrm{S} 4 \dagger$ ) generated by symmetry with respect to the inversion centre of the unit cell. The structure of 2 showed a distorted pseudo-trigonal bipyramidal environment around antimony (Fig. 2 and Table 1 ) due to the internal coordination of the $\mathrm{Me}_{2} \mathrm{~N}$ group trans to the $\mathrm{Sb}(1)-\mathrm{C}(10)$ bond $[\mathrm{N}(1)-$ $\left.\mathrm{Sb}(1)-\mathrm{C}(10) 162.40(11)^{\circ}\right]$. The other two carbon atoms and the lone pair of electrons are in equatorial positions. The $\mathrm{Sb}-\mathrm{N}$ distance in 2 [Sb(1)-N(1) 3.052(3) $\mathrm{A}]$ is considerably longer than in compound 1 [N(1)- $\mathrm{Sb}(1) 2.452(2) \AA]$.

In the crystal of 2 there is an intramolecular $\mathrm{C}-\mathrm{H}_{N \text {-methyl }} \cdots \mathrm{Cg}$ interaction between the hydrogen atom of a methyl group bonded to nitrogen and the centroid of the mesityl group placed in equatorial position $\left[\mathrm{C}(9)-\mathrm{H}(9 \mathrm{~B}) \cdots \mathrm{Cg}(3) 2.92 \AA, \gamma=9.7^{\circ}\right]$ (see ESI, Fig. S5 and Table S2 $\dagger$ ).

The X-ray analyses revealed that despite the different approaches of synthesis, always the ionic complex $\left[\mathrm{Me}_{2} \mathrm{NHCH}_{2} \mathrm{C}_{6} \mathrm{H}_{5}\right]^{+}\left[\mathrm{PdCl}_{3}\left\{\mathrm{SbCl}(\mathrm{Ph})\left(\mathrm{C}_{6} \mathrm{H}_{4} \mathrm{CH}_{2} \mathrm{NMe}_{2}-2\right)-\mathrm{Sb}\right\}\right]^{-}$(3) is formed as a racemate of $\left(R_{\mathrm{N}}, A_{\mathrm{Sb}}\right)$ and $\left(S_{\mathrm{N}}, C_{\mathrm{Sb}}\right)$ isomers (see ESI, Fig. S6 ${ }^{\dagger}$ ). In the anion of 3 (Fig. 3 ) the stibine ligand adopts a distorted trigonal bipyramidal geometry at the antimony centre, i.e. two carbon atoms and the palladium atom occupy the equatorial sites, while the chlorine and the nitrogen atoms adopt the axial positions $\left[\mathrm{N}(1)-\mathrm{Sb}(1)-\mathrm{Cl}(1) 167.05(16)^{\circ}\right]$. The antimony centre is strongly coordinated by the nitrogen atom of the pendant arm. The antimony-nitrogen bond in $3[\mathrm{~N}(1)-\mathrm{Sb}(1)$ $2.385(6) \AA]$ is slightly shorter than in 1 [N(1)-Sb(1) 2.452(2) $\mathrm{A}]$.

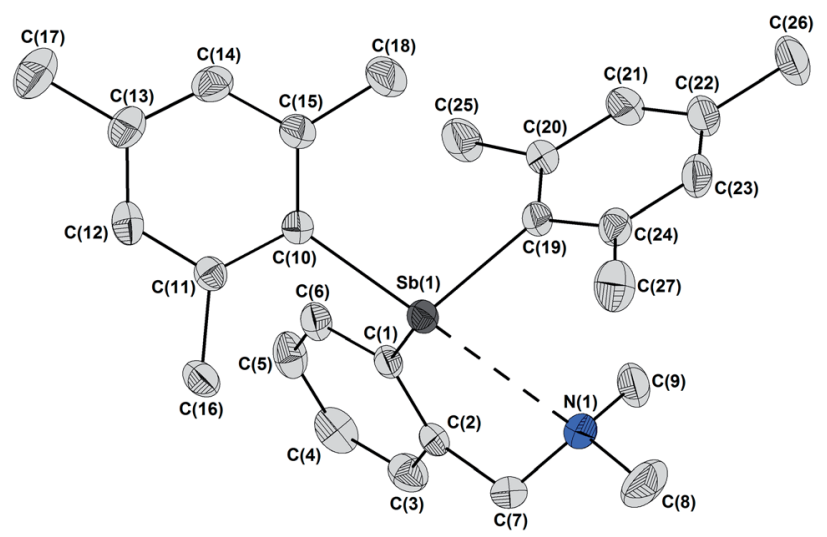

Fig. 2 Displacement ellipsoid representation (30\% probability level) of $\left(R_{\mathrm{N}}, C_{\mathrm{Sb}}\right)-2$ isomer. The hydrogen atoms were omitted for clarity.

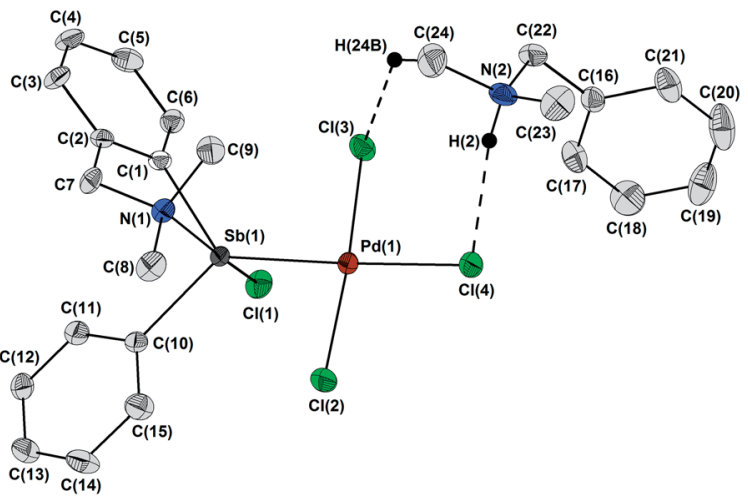

Fig. 3 Displacement ellipsoid representation (30\% probability level) of $\left(S_{N}, C_{S b}\right)-3$ isomer. The hydrogen atoms except those involved in cation/anion interactions were omitted for clarity.

The palladium atom is in the centre of a slightly distorted square planar $\mathrm{SbPdCl}_{3}$ core. The sum of the four cis bond angles at palladium atom is $360.01^{\circ}$ (Table 2), but the values of the trans bond angles are $\mathrm{Sb}(1)-\mathrm{Pd}(1)-\mathrm{Cl}(4) 177.71(6)^{\circ}$ and $\mathrm{Cl}(2)-$ $\operatorname{Pd}(1)-\mathrm{Cl}(3) 174.36(9)^{\circ}$, respectively. The $\mathrm{Pd}(1)-\mathrm{Cl}(4)$ bond trans to the antimony atom is slightly longer than the $\mathrm{Pd}(1)-\mathrm{Cl}(2)$ and $\operatorname{Pd}(1)-\mathrm{Cl}(3)$ bonds $[2.360(2) \AA$ vs. $2.288(2)$ and $2.302(2) \AA$ respectively], but all these values are in the range of $\mathrm{Pd}-\mathrm{Cl}$ bonds observed in similar Pd(II) complexes (2.288-2.411 A). ${ }^{14,18,21,23,33}$ The $\operatorname{Pd}(1)-\mathrm{Sb}(1)$ bond length [2.4783(8) $\left.\mathrm{A}\right]$ has

Table 2 Selected interatomic distances $(\AA)$ and angles $\left(^{\circ}\right)$ in 3 and 4

\begin{tabular}{|c|c|c|c|}
\hline 3 & & 4 & \\
\hline $\mathrm{Sb}(1)-\operatorname{Pd}(1)$ & $2.4783(8)$ & $\operatorname{Sb}(1)-\operatorname{Pd}(1)$ & $2.4831(5)$ \\
\hline $\mathrm{Sb}(1)-\mathrm{C}(1)$ & $2.108(7)$ & $\mathrm{Sb}(1)-\mathrm{C}(1)$ & $2.131(4)$ \\
\hline $\mathrm{Sb}(1)-\mathrm{C}(10)$ & $2.130(8)$ & $\mathrm{Sb}(1)-\mathrm{C}(10)$ & $2.133(4)$ \\
\hline $\mathrm{Sb}(1)-\mathrm{Cl}(1)$ & $2.487(2)$ & $\mathrm{Sb}(1)-\mathrm{C}(19)$ & $2.147(4)$ \\
\hline $\mathrm{Sb}(1)-\mathrm{N}(1)$ & $2.385(6)$ & & \\
\hline $\operatorname{Pd}(1)-\mathrm{Cl}(2)$ & $2.288(2)$ & $\operatorname{Pd}(1)-\mathrm{Cl}(1)$ & $2.3029(13)$ \\
\hline $\operatorname{Pd}(1)-\mathrm{Cl}(3)$ & $2.302(2)$ & $\operatorname{Pd}(1)-\mathrm{Cl}(2)$ & $2.3769(13)$ \\
\hline $\operatorname{Pd}(1)-\mathrm{Cl}(4)$ & $2.360(2)$ & $\operatorname{Pd}(1)-N(1)$ & $2.133(4)$ \\
\hline $\mathrm{N}(1)-\mathrm{Sb}(1)-\mathrm{Cl}(1)$ & $167.05(16)$ & $C(1)-S b(1)-C(10)$ & $103.64(17)$ \\
\hline$C(1)-S b(1)-C(10)$ & $102.4(3)$ & $\mathrm{C}(1)-\mathrm{Sb}(1)-\mathrm{C}(19)$ & $100.23(17)$ \\
\hline $\mathrm{C}(1)-\mathrm{Sb}(1)-\mathrm{Pd}(1)$ & $128.4(2)$ & $C(10)-S b(1)-C(19)$ & $115.40(16)$ \\
\hline $\mathrm{C}(10)-\mathrm{Sb}(1)-\mathrm{Pd}(1)$ & $128.4(2)$ & $\mathrm{Pd}(1)-\mathrm{Sb}(1)-\mathrm{C}(1)$ & $103.49(12)$ \\
\hline $\mathrm{Cl}(1)-\mathrm{Sb}(1)-\mathrm{C}(1)$ & $91.4(2)$ & $\mathrm{Pd}(1)-\mathrm{Sb}(1)-\mathrm{C}(10)$ & $110.42(11)$ \\
\hline $\mathrm{Cl}(1)-\mathrm{Sb}(1)-\mathrm{C}(10)$ & $91.1(2)$ & $\mathrm{Pd}(1)-\mathrm{Sb}(1)-\mathrm{C}(19)$ & $120.68(13)$ \\
\hline $\mathrm{Cl}(1)-\mathrm{Sb}(1)-\mathrm{Pd}(1)$ & $95.65(6)$ & & \\
\hline $\mathrm{N}(1)-\mathrm{Sb}(1)-\mathrm{C}(1)$ & $76.0(3)$ & & \\
\hline $\mathrm{N}(1)-\mathrm{Sb}(1)-\mathrm{C}(10)$ & $88.8(3)$ & & \\
\hline $\mathrm{N}(1)-\mathrm{Sb}(1)-\mathrm{Pd}(1)$ & $94.61(16)$ & & \\
\hline $\mathrm{Sb}(1)-\mathrm{Pd}(1)-\mathrm{Cl}(4)$ & $177.71(6)$ & $\mathrm{Sb}(1)-\mathrm{Pd}(1)-\mathrm{Cl}(2)$ & $168.34(4)$ \\
\hline $\mathrm{Cl}(2)-\operatorname{Pd}(1)-\mathrm{Cl}(3)$ & $174.36(9)$ & $\mathrm{N}(1)-\mathrm{Pd}(1)-\mathrm{Cl}(1)$ & $173.96(12)$ \\
\hline $\mathrm{Sb}(1)-\mathrm{Pd}(1)-\mathrm{Cl}(2)$ & $90.88(6)$ & $\mathrm{Sb}(1)-\mathrm{Pd}(1)-\mathrm{N}(1)$ & $94.55(11)$ \\
\hline $\mathrm{Cl}(2)-\operatorname{Pd}(1)-\mathrm{Cl}(4)$ & $91.40(8)$ & $\mathrm{N}(1)-\operatorname{Pd}(1)-\mathrm{Cl}(2)$ & $92.60(11)$ \\
\hline $\mathrm{Cl}(4)-\mathrm{Pd}(1)-\mathrm{Cl}(3)$ & $93.97(8)$ & $\mathrm{Cl}(2)-\mathrm{Pd}(1)-\mathrm{Cl}(1)$ & $91.51(5)$ \\
\hline $\mathrm{Cl}(3)-\operatorname{Pd}(1)-\mathrm{Sb}(1)$ & $83.76(6)$ & $\mathrm{Cl}(1)-\mathrm{Pd}(1)-\mathrm{Sb}(1)$ & $82.12(3)$ \\
\hline
\end{tabular}


similar value as in related palladium(II) complexes (2.493$2.575 \AA$ ̊). ${ }^{11,14,17-19,21,22,24,33}$

In the crystal of 3 there are two hydrogen interactions between the anion and the cation, i.e. $\mathrm{N}(2)-\mathrm{H}(2) \cdots \mathrm{Cl}(4) 2.25(6) \AA$ and $\mathrm{C}(24)-\mathrm{H}(24 \mathrm{~B}) \cdots \mathrm{Cl}(3) 2.69 \AA$ A. Such cation/anion pairs are connected to neighbouring pairs by $\mathrm{C}-\mathrm{H}_{\text {methyl(cation) }} \cdots \mathrm{Cl}$ interactions involving only the chlorine atom bonded to antimony as well as $\mathrm{C}-\mathrm{H}_{\text {aryl(cation) }}{ }^{\cdots} \mathrm{Cg}$ and $\mathrm{C}-\mathrm{H}_{\text {methyl(cation) }}{ }^{\cdots} \mathrm{Cg}$ interactions with the aromatic rings attached to antimony (see ESI, Table S3 and Fig. S7†).

The aliphatic region of the ${ }^{1} \mathrm{H}$ NMR spectrum recorded in $\mathrm{CDCl}_{3}$ for 3 shows that the methyl groups from 2- $\mathrm{Me}_{2} \mathrm{NCH}_{2} \mathrm{C}_{6} \mathrm{H}_{4}$ moiety are not equivalent (two singlet resonances at $\delta 2.24$ and $3.26 \mathrm{ppm}$, respectively), while the methylene protons appear as an $\mathrm{AB}$ spin system $\left(\delta_{\mathrm{A}}\right.$ at $3.61 \mathrm{ppm}$ and $\delta_{\mathrm{B}}$ at $3.89 \mathrm{ppm},{ }^{2} J_{\mathrm{HH}}=$ $14.3 \mathrm{~Hz}$ ), consistent with strong coordination of nitrogen to antimony in solution. The proton attached to the nitrogen atom of the cation $\left[\mathrm{Me}_{2} \mathrm{NHCH}_{2} \mathrm{C}_{6} \mathrm{H}_{5}\right]^{+}$is observed at $\delta 9.88 \mathrm{ppm}$ as a broad singlet signal. The ${ }^{13} \mathrm{C}$ NMR spectrum exhibits in aliphatic region singlet signals for the different atoms, i.e. $\delta$ 43.36 and $62.01 \mathrm{ppm}$ for the $\mathrm{NMe}_{2}$ and $\mathrm{CH}_{2}$ carbon atoms of the $\left[\mathrm{Me}_{2} \mathrm{NHCH}_{2} \mathrm{C}_{6} \mathrm{H}_{5}\right]^{+}$cation; $\delta 46.65,48.86$ and $64.28 \mathrm{ppm}$ for two different methyl carbons and $\mathrm{CH}_{2}$ carbon atom, respectively, of the $2-\mathrm{Me}_{2} \mathrm{NCH}_{2} \mathrm{C}_{6} \mathrm{H}_{4}$ moiety. Thus the NMR data suggest that the structure observed for complex 3 in solid-state is preserved in solution too.

The molecular structure of $\left[\mathrm{PdCl}_{2}\left\{\mathrm{SbMes}_{2}\left(\mathrm{C}_{6} \mathrm{H}_{4} \mathrm{CH}_{2} \mathrm{NMe}_{2}-2\right)\right.\right.$ $N, S b\}]$ (4) revealed one rare example of a neutral $\mathrm{Pd}(\mathrm{II})$ complex which contains a $\mathrm{Pd}-\mathrm{Cl}$ bond trans to an antimony atom. The crystal contains a racemate of $\left(S_{\mathrm{N}}\right)$ and $\left(C_{\mathrm{N}}\right)$ isomers (see ESI, Fig. S8 $\dagger$ ). The stibine molecule acts as a bidentate chelating $(S b, N)$-type ligand with respect to palladium (Fig. 4), thus resulting in a distorted tetrahedral geometry with angles at the antimony atom in the range $100.23(17)-120.68(13)^{\circ}$ (Table 2). The palladium atom is in a distorted square planar geometry reflected in the bond angles: the sum of the four cis bond angles at palladium atom is $360.78^{\circ}$, while the trans bond angles are $\mathrm{Sb}(1)-\mathrm{Pd}(1)-\mathrm{Cl}(2) 168.34(4)^{\circ}$ and $\mathrm{N}(1)-\mathrm{Pd}(1)-\mathrm{Cl}(1)$ 173.96(12) ${ }^{\circ}$, respectively. The $\operatorname{Pd}(1)-\mathrm{Cl}(2)$ bond $[2.3769(13) \AA]$ trans to the

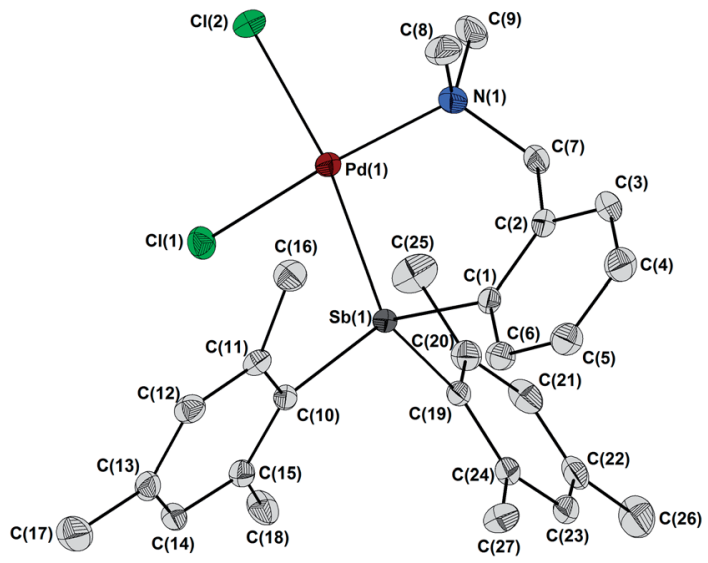

Fig. 4 Displacement ellipsoid representation (25\% probability level) of $\left(S_{N}\right)$-4 isomer. The hydrogen atoms were omitted for clarity. antimony atom is slightly longer than the $\operatorname{Pd}(1)-\mathrm{Cl}(1)$ bond $[2.3029(13) \AA]$ trans to nitrogen, but in the same range as observed for the anion of complex 3. The $\operatorname{Pd}(1)-\mathrm{N}(1)$ bond $\left[\begin{array}{ll}2.133(4) & \AA\end{array}\right]$ is similar with the value found in $\left[\mathrm{PdCl}\left(\mathrm{C}_{6} \mathrm{H}_{4} \mathrm{CH}_{2} \mathrm{NMe}_{2}-2\right)\left(\mathrm{SbPh}_{3}\right)\right][2.134(2) \AA] .{ }^{33}$ The bond length $\mathrm{Pd}(1)-\mathrm{Sb}(1)[2.4831(5) \AA]$ has a similar value as observed in the anion of complex 3 [2.4783(8) $\mathrm{\circ}]$.

A 3D supramolecular structure is formed in the crystal of $\mathbf{4}$, based on a $\mathrm{C}-\mathrm{H}_{\text {methyl(mesityl) }}{ }^{\cdots} \mathrm{Cl}$ contact and $\mathrm{C}-\mathrm{H}_{\text {aryl }}{ }^{\cdots} \mathrm{Cg}_{\text {mesityl }}$ interactions which involves both mesityl aromatic rings (see ESI, Table S4 and Fig. S9†).

The NMR spectra of complex 4 are consistent with the coordination of the stibine 2 to palladium. In the ${ }^{1} \mathrm{H}$ spectrum in $\mathrm{CDCl}_{3}$, at room temperature, the methylene protons from 2$\mathrm{Me}_{2} \mathrm{NCH}_{2} \mathrm{C}_{6} \mathrm{H}_{4}$ moiety appear as an $\mathrm{AB}$ spin system, partially overlapped by the resonance of a methyl group attached to nitrogen. The ${ }^{13} \mathrm{C}$ NMR spectrum exhibits in aliphatic region three singlet signals for two different methyl carbons and $\mathrm{CH}_{2}$ carbon atom, respectively, of the $2-\mathrm{Me}_{2} \mathrm{NCH}_{2} \mathrm{C}_{6} \mathrm{H}_{4}$ moiety. Only one set of resonances were observed for the mesityl substituents. While the methyl groups from the para position gave a sharp resonance, the resonance (either the ${ }^{1} \mathrm{H}$ or the ${ }^{13} \mathrm{C}$ one) for the ortho methyl groups of the mesityl ligands is broad as is the ${ }^{1} \mathrm{H}$ resonance observed in the aromatic region for the protons of the mesityl groups. This suggests that, in contrast to the behaviour observed for the free stibine $2,{ }^{25}$ following the coordination to the palladium atom the free rotation of the mesityl groups around the $\mathrm{Sb}-\mathrm{C}_{\text {mesityl }}$ bond is slow at room temperature. A similar behaviour was also observed in the case of $\left[2-\mathrm{Me}_{2} \mathrm{NCH}_{2} \mathrm{C}_{6} \mathrm{H}_{4}\right] \mathrm{MesSbX}(\mathrm{X}=\mathrm{Br}, \mathrm{I}){ }^{25}$

\section{Theoretical studies}

Theoretical calculations at DFT level were carried out in order to better understand the behaviour of $\mathbf{1}$ and $\mathbf{2}$ as ligands in the coordination sphere of palladium.

The values of the bond lengths and angles around the metal centres obtained by theoretical calculations compare well to those obtained from the X-ray diffraction data (for the data comparison see ESI, Tables S5-S6 and Fig. S10-S13†).

For 1 the largest difference (abs. err. $0.21 \AA$ ) between the calculated and determined values was found for the $\mathrm{Sb}-\mathrm{N}$ bond length. All calculated bond lengths that involve antimony are close to the values experimentally determined. With only one exception (for 1, $\mathrm{N}(1)-\mathrm{Sb}(1)-\mathrm{C}(10)$ rel. err. $7.3 \%$ ), the angles around the antimony in the calculated structures of $\mathbf{1}$ and $\mathbf{2}$ have relative errors smaller than $5 \%$.

Similar differences were also observed between the calculated and determined structures for the anion of $\mathbf{3}$ and for the neutral complex 4 . Thus, in the calculated anion of 3 , as in $\mathbf{1}$, the $\mathrm{Sb}-\mathrm{N}$ bond length is with $0.25 \AA$ shorter whereas the $\mathrm{Sb}-\mathrm{Cl}$ is $0.02 \AA$ longer than the determined values. There are two angles around the antimony that have values with a relative error larger than $10 \%$ (see ESI, Table S7†). These large differences that correspond to the orientation of the $\mathrm{PdCl}_{3}$ fragment (see ESI, Fig. S12†) most likely are a consequence of inter- and intramolecular $\mathrm{C}-\mathrm{H} \cdots \mathrm{Cl}$ and $\mathrm{C}-\mathrm{H} \cdots \mathrm{Cg}$ interactions (see ESI, 
Fig. S7 $\dagger$ ) that were neglected in the gas phase. The bond lengths around $\mathrm{Sb}$ and $\mathrm{Pd}$ in the calculated structure of $\mathbf{4}$ are in good agreement with the determined values and there is only one bond angle with a relative error larger than 5\% (see ESI, Table S8 and Fig. S13†).

In order to calculate the stabilization energy brought in $\mathbf{1}$ and 2 by the intramolecular coordination, the structures with nitrogen atom uncoordinated to the antimony were optimized. The results show that the structures exhibiting intramolecular coordination are lower in energy (10.55 and $3.59 \mathrm{kcal} \mathrm{mol}^{-1}$ for 1 and 2 , respectively) than the structures where the pendant arm is not coordinated. These energies are consistent to the previously reported solution behaviour of compounds 1 and $2 .^{25}$ Thus, while for $\mathbf{1}$ the pendant arm is strong coordinated in solution to the metal centre, as suggested by the $\mathrm{AB}$ spin system for the $\mathrm{CH}_{2}$ group observed in the ${ }^{1} \mathrm{H}$ NMR spectrum, in 2 the ${ }^{1} \mathrm{H}$ NMR spectrum exhibits only a singlet resonance for the methylene group.

The second order perturbation theory analysis of Fock matrix in NBO basis reveals that in $\mathbf{1}$ the stabilization brought by the donation from the $\mathrm{N}$ atom lone pair into the $\mathrm{Sb}-\mathrm{Cl}$ antibonding orbital is $13.71 \mathrm{kcal} \mathrm{mol}^{-1}$, whereas in 2 the donation takes place into the $\mathrm{Sb}-\mathrm{C}$ antibonding orbital in position trans to $\mathrm{N}$ bringing a stabilization of $3.79 \mathrm{kcal} \mathrm{mol}^{-1}$. The lone pair of $\mathrm{Sb}$ has mainly $s$ character both in 1 (74.28\%) and in $2(65.70 \%)$.

In the anion of $\mathbf{3}$, the coordinative bond is formed by donation of the lone pair of antimony to the $\mathrm{Pd}-\mathrm{Cl}$ antibonding orbital. This donation affords a stabilization of $73.24 \mathrm{kcal} \mathrm{mol}^{-1}$ of the system. As in $\mathbf{1}$, the $\mathrm{Sb}-\mathrm{N}$ coordination is formed by donation of the $\mathrm{N}$ atom lone pair into the trans $\mathrm{Sb}-\mathrm{Cl}$ antibonding orbital, which gives, in this case, a stabilization energy of $17.30 \mathrm{kcal} \mathrm{mol}^{-1}$. The experimentally observed $\mathrm{Sb}-\mathrm{N}$ bond length shortening in $\mathbf{3}$ is also reflected in Wiberg bond indices found for the calculated geometries. Thus, in 1 the Wiberg bond index for $\mathrm{Sb}-\mathrm{N}$ bond is $\mathbf{0 . 1 6 6 9}$, whereas in 3 , for the same bond it is 0.1764 .

In 4 the $\mathrm{Sb}-\mathrm{Pd}$ coordinative bond has a contribution of $70.26 \%$ from the hybrid orbitals located on antimony, in which there is a large contribution (74.89\%) from p orbitals. This contribution accounts presumably for the expansion of the $\mathrm{C}-$ $\mathrm{Sb}-\mathrm{C}$ angles in 4 , which have a sum of $313.66^{\circ}\left(319.3^{\circ}\right.$ determined from the crystallographic data), considerably larger than in the free ligand 2 (calculated: $299.05^{\circ}$; determined: $301.9^{\circ}$ ). The nitrogen atom lone pair is donated into $\mathrm{Pd}-\mathrm{Cl}$ antibonding orbitals and brings, according to the second order perturbation theory analysis of Fock matrix in NBO basis, a stabilization energy of $29 \mathrm{kcal} \mathrm{mol}^{-1}$. The same analysis reveals also a considerable stabilization (62.83 kcal $\mathrm{mol}^{-1}$ ) from electron donation from the chlorine atom lone pair in position trans to antimony into a Sb-Pd antibonding orbital.

Another possible structure for the complex of stoichiometry $\left[\mathrm{PdCl}_{2}\left\{\mathrm{SbMes}_{2}\left(\mathrm{C}_{6} \mathrm{H}_{4} \mathrm{CH}_{2} \mathrm{NMe}_{2}-2\right)\right\}\right]$ was also investigated. In this potential structure the pendant arm ligand retains its $(C, N)$ coordination pattern found in the free stibine 2 and the antimony atom is coordinated to a $\mathrm{PdCl}_{2}$ unit, similar to the coordination pattern found in 3 (see ESI, Fig. S14 $\dagger$ ). This structure was found to have an energy minimum which was confirmed by the absence of imaginary frequencies. Nevertheless the energy of this potential structure is $12.91 \mathrm{kcal} \mathrm{mol}^{-1}$ higher than for $\mathbf{4}$, and thus suggests that the stibine 2 prefers to coordinate as a $(N, S b)$-chelating ligand in the coordination sphere of $\operatorname{Pd}(\mathrm{II})$.

\section{Conclusions}

We have described the synthesis of two chiral stibines with the 2- $\mathrm{Me}_{2} \mathrm{NCH}_{2} \mathrm{C}_{6} \mathrm{H}_{4}$ group. As expected the air-stable compounds exhibit intramolecular $\mathrm{N} \rightarrow \mathrm{Sb}$ interactions in solid state, which were found to induce chirality at the metal centre. The use of these organoantimony compounds as ligands in palladium(II) complexes was investigated and their versatile nature was proved by different coordination modes. Compound 1 acts as a monodentate ligand toward $\mathrm{PdCl}_{2}$, all the synthesis procedures applied in this work producing the same air-stable ionic species $\left[\mathrm{Me}_{2} \mathrm{NHCH}_{2} \mathrm{C}_{6} \mathrm{H}_{5}\right]^{+}\left[\mathrm{PdCl}_{3}\left\{\mathrm{SbCl}(\mathrm{Ph})\left(\mathrm{C}_{6} \mathrm{H}_{4} \mathrm{CH}_{2} \mathrm{NMe}_{2}-2\right)\right\}\right]^{-}$ (3), probably due to a $\mathrm{Sb}-\mathrm{C}$ bond cleavage. Compound 2 acts as a $(N, S b)$-chelating ligand and the expected neutral complex $\left[\mathrm{PdCl}_{2}\left\{\mathrm{SbMes}_{2}\left(\mathrm{C}_{6} \mathrm{H}_{4} \mathrm{CH}_{2} \mathrm{NMe}_{2}-2\right)-N, S b\right\}\right]$ was obtained. Theoretical calculations showed that the intramolecular coordination in $\mathbf{1}$ and $\mathbf{2}$ is mainly the result of electron donation of the nitrogen atom lone pair into antimony-element antibonding orbitals, where the element ( $\mathrm{Cl}$ in $\mathbf{1}$, and $\mathrm{C}$ in 2 ) is located in position trans to nitrogen. As also observed from the experimental data, upon coordination of $\mathbf{1}$ to the palladium centre, the stibine ligand retains its geometry and the $\mathrm{Sb}-\mathrm{N}$ intramolecular coordination is strengthened. By contrast, it is more energetically favourable for ligand 2 to act as a $(N, S b)$-chelating ligand in the coordination sphere of palladium.

\section{Experimental}

\section{General procedures}

All manipulations of air sensitive derivatives were carried out under inert atmosphere, using Schlenk techniques. Solvents were dried and freshly distilled under argon or nitrogen prior to use. $N, N$-Dimethylbenzylamine was commercially available. 1 and 2 were prepared according to literature methods. ${ }^{25}$

The ${ }^{1} \mathrm{H}$ and ${ }^{13} \mathrm{C}\left\{{ }^{1} \mathrm{H}\right\}$ NMR spectra for 3 and $\mathbf{4}$ were recorded at room temperature on a Bruker Avance 300 . The chemical shifts are reported in ppm relative to the residual peak of solvent in ${ }^{1} \mathrm{H}$ NMR (ref. $\mathrm{CHCl}_{3}:{ }^{1} \mathrm{H}$ 7.26) or the resonance of the deuterated solvent in ${ }^{13} \mathrm{C}\left\{{ }^{1} \mathrm{H}\right\} \quad$ NMR (ref. ${ }^{13} \mathrm{CDCl}_{3}$ : $77.00 \quad \mathrm{ppm}$ ). Elemental analyses were carried out at Università degli Studi di Cagliari, Dipartimento di Chimica Inorganica ed Analitica, Cagliari, Italy.

\section{Preparation of $\left[\mathrm{Me}_{2} \mathrm{NHCH}_{2} \mathrm{C}_{6} \mathrm{H}_{5}\right]^{+}\left[\mathrm{PdCl}_{3}\left\{\operatorname{SbCl}(\mathrm{Ph})\left(\mathrm{C}_{6} \mathrm{H}_{4}-\right.\right.\right.$ $\left.\left.\left.\mathrm{CH}_{2} \mathrm{NMe}_{2}-2\right)-S b\right\}\right]^{-}$(3)}

Method A. A solution of $\left(2-\mathrm{Me}_{2} \mathrm{NCH}_{2} \mathrm{C}_{6} \mathrm{H}_{4}\right) \mathrm{PhSbCl}(\mathbf{1})(0.207$ $\mathrm{g}, 0.56 \mathrm{mmol})$ in $\mathrm{CHCl}_{3}(35 \mathrm{ml})$ was added dropwise to a solution of $\left[\mathrm{PdCl}_{2}\left(\mathrm{MeCN}_{2}\right](0.10 \mathrm{~g}, 0.56 \mathrm{mmol})\right.$ in acetonitrile (30 $\mathrm{ml}$ ) and stirred at room temperature for $30 \mathrm{~h}$, under a $\mathrm{N}_{2}$ atmosphere. The reaction mixture was filtered off and the solvents removed under vacuum. The brown oil obtained was 
recrystallized from $\mathrm{CH}_{2} \mathrm{Cl}_{2}$ to afford $3(0.13 \mathrm{~g}, 42 \%)$ as brown solid. Mp $163{ }^{\circ} \mathrm{C}$. Anal. found: C, 40.03; H, 4.56; N, 3.62. Calc. for $\mathrm{C}_{24} \mathrm{H}_{31} \mathrm{Cl}_{4} \mathrm{~N}_{2} \mathrm{PdSb}$ (717.51): C, 40.17; H, 4.35; N, 3.90\%. FTRaman $\left(\nu, \mathrm{cm}^{-1}, 350 \mathrm{~mW}\right)\left(4000-50 \mathrm{~cm}^{-1}\right.$; solid state, relative intensities in parentheses related to the highest peak taken equal to 10.0): 112 (9.8), 196 (8.4), 228 (10), 324 (7.5), 376 (6.6). ${ }^{1} \mathrm{H}$ NMR (300 MHz, $\left.\mathrm{CDCl}_{3}\right): \delta 2.24\left(3 \mathrm{H}, \mathrm{s}, \mathrm{CH}_{3}\right.$-anion), $3.02(6 \mathrm{H}$, d, $\mathrm{CH}_{3}$-cation, $\left.{ }^{3} J_{\mathrm{HH}} 5.0 \mathrm{~Hz}\right), 3.26\left(3 \mathrm{H}, \mathrm{s}, \mathrm{CH}_{3}\right.$-anion), AB spin system with A at 3.61 and $B$ at $3.89 \mathrm{ppm}\left(2 \mathrm{H},{ }^{2} J_{\mathrm{HH}}=14.3 \mathrm{~Hz}\right)$, $4.41\left(2 \mathrm{H}, \mathrm{d}, \mathrm{CH}_{2}\right.$-cation, $\left.{ }^{3} \mathrm{~J}_{\mathrm{HH}} 5.0 \mathrm{~Hz}\right), 7.42\left(9 \mathrm{H}, \mathrm{m}, \mathrm{C}_{6} \mathrm{H}_{4}+\mathrm{C}_{6} \mathrm{H}_{5}-\right.$ anion $+\mathrm{C}_{6} \mathrm{H}_{5}$-cation), $7.61\left(2 \mathrm{H}, \mathrm{m}, \mathrm{C}_{6} \mathrm{H}_{5}\right.$-cation), $7.94(2 \mathrm{H}, \mathrm{m}$, $\mathrm{C}_{6} \mathrm{H}_{5}$-anion), 8.41 (1H, m, $\left.\mathrm{C}_{6} \mathrm{H}_{4}\right), 9.87\left(1 \mathrm{H}\right.$, br s). ${ }^{13} \mathrm{C}\left\{{ }^{1} \mathrm{H}\right\} \mathrm{NMR}$ (75.42 $\mathrm{MHz}, \mathrm{CDCl}_{3}$ ): $\delta 43.36\left(\mathrm{~s}, \mathrm{CH}_{3}\right.$-cation), $46.65\left(\mathrm{~s}, \mathrm{CH}_{3}\right.$ anion), 48.86 (s, $\mathrm{CH}_{3}$-anion), 62.01 (s, $\mathrm{CH}_{2}$-cation), 64.28 (s, $\mathrm{CH}_{2}$-anion), 127.14, 128.15, 129.17, 129.29, 129.59, 130.52, 130.90, 131.35, 131.38, 131.59, 134.88, 138.01, 138.54, 140.89 $\left(\mathrm{C}_{6} \mathrm{H}_{4}, \mathrm{C}_{6} \mathrm{H}_{5}\right.$-anion, $\mathrm{C}_{6} \mathrm{H}_{5}$-cation $)$.

Method B. A solution of $1(0.4156 \mathrm{~g}, 1.12 \mathrm{mmol})$ in $\mathrm{CHCl}_{3}$ $(25 \mathrm{ml})$ was added dropwise to a solution of $\left[\mathrm{PdCl}_{2}(\mathrm{MeCN})_{2}\right]$ $(0.10 \mathrm{~g}, 0.56 \mathrm{mmol})$ in acetonitrile $(30 \mathrm{ml})$ and stirred at room temperature for $4 \mathrm{~h}$, under a $\mathrm{N}_{2}$ atmosphere. The reaction mixture was filtered off and the solvents removed under vacuum. The brown solid obtained $(0.485 \mathrm{~g}, 94 \%)$ was dried under vacuum.

Method C. A solution of $1(0.108 \mathrm{~g}, 0.29 \mathrm{mmol})$ in $\mathrm{CH}_{2} \mathrm{Cl}_{2}$ $(40 \mathrm{ml})$ was added dropwise to a solution of $\mathrm{PdCl}_{2}(0.052 \mathrm{~g}$, $0.29 \mathrm{mmol})$ in $\mathrm{CH}_{2} \mathrm{Cl}_{2}(15 \mathrm{ml})$. The reaction mixture was refluxed for 3 hours and then stirred at room temperature for 10 hours, under an argon atmosphere. After the filtration, $n$-hexane is layered upon the brown solution and the mixture is maintained at $-28{ }^{\circ} \mathrm{C}$ for several weeks to afford brown crystals $(0.070 \mathrm{~g}, 44 \%)$.

Method D. A solution of $1(0.0972 \mathrm{~g}, 0.26 \mathrm{mmol})$ in $\mathrm{CH}_{2} \mathrm{Cl}_{2}$ $(30 \mathrm{ml})$ and $\left[\mathrm{Me}_{2} \mathrm{NHCH}_{2} \mathrm{C}_{6} \mathrm{H}_{5}\right]^{+} \mathrm{Cl}^{-}(0.0453 \mathrm{~g}, 0.26 \mathrm{mmol})$ were added dropwise to a solution of $\left[\mathrm{PdCl}_{2}(\mathrm{MeCN})_{2}\right](0.0467 \mathrm{~g}, 0.26$ $\mathrm{mmol})$ in acetonitrile $(15 \mathrm{ml})$. The reaction mixture was stirred for 3 hours at room temperature, and then filtered off under an argon atmosphere. After filtration and the removal of the solvents, the solid product was dissolved in $\mathrm{CH}_{2} \mathrm{Cl}_{2}$ and $n$ hexane is layered upon the yellow solution, which is maintained at room temperature for several days to afford air-stable brown crystals $(0.091 \mathrm{~g}, 48 \%)$.

\section{Preparation of $\left[\mathrm{PdCl}_{2}\left\{\mathrm{SbMes}_{2}\left(\mathrm{C}_{6} \mathrm{H}_{4} \mathrm{CH}_{2} \mathrm{NMe}_{2}-2\right)-\mathrm{N}, \mathrm{Sb}\right\}\right]$ (4)}

A mixture of (2- $\left.\mathrm{Me}_{2} \mathrm{NCH}_{2} \mathrm{C}_{6} \mathrm{H}_{4}\right) \mathrm{Mes}_{2} \mathrm{Sb}(2)(0.1288 \mathrm{~g}, 0.26 \mathrm{mmol})$ and $\left[\mathrm{PdCl}_{2}(\mathrm{COD})\right](0.122 \mathrm{~g}, 0.26 \mathrm{mmol})$ were refluxed in $\mathrm{CHCl}_{3}$ (30 ml) for $4 \mathrm{~h}$, under a $\mathrm{N}_{2}$ atmosphere. The solvent was removed under vacuum. The obtained yellow solid $(0.193 \mathrm{~g}$, $87 \%$ ) was dried under vacuum. Yellow crystals suitable for X-ray diffraction were obtained from $\mathrm{CH}_{2} \mathrm{Cl}_{2}-n$-hexane ( $1: 1 \mathrm{v} / \mathrm{v}$ ratio). Mp: $170{ }^{\circ} \mathrm{C}$. Anal. found: C, 48.16; H, 5.06; N, 1.95. Calc. for $\mathrm{C}_{27} \mathrm{H}_{34} \mathrm{Cl}_{2} \mathrm{NPdSb}$ (671.65): C, 48.28; H, 5.10; N, 2.09\%. FTRAMAN: not active. ${ }^{1} \mathrm{H}$ NMR $\left(300 \mathrm{MHz} \mathrm{CDCl}_{3}\right): \delta$ 2-2.7 (br, ortho- $\mathrm{CH}_{3}$ ), 2.28 (s, para- $\mathrm{CH}_{3}$ ), 2.55 (br s, $\left.\mathrm{NCH}_{3}\right), 3.22(4 \mathrm{H}$, br s, $\mathrm{NCH}_{3}$ + half of the AB system of the $\mathrm{CH}_{2}$ group), AB spin system with A overlapped with the resonance of a $\mathrm{NCH}_{3}$ group and $\mathrm{B}$ at $3.51 \mathrm{ppm}\left(1 \mathrm{H},{ }^{2} \mathrm{~J}_{\mathrm{HH}}=12.9 \mathrm{~Hz}\right), 6.92\left(4 \mathrm{H}\right.$, br s, $\left.\mathrm{C}_{6} \mathrm{H}_{2}\right), 7.20(1 \mathrm{H}$, dd, $\left.\mathrm{C}_{6} \mathrm{H}_{4},{ }^{3} J_{\mathrm{HH}} 7.1,{ }^{4} J_{\mathrm{HH}} 2.2 \mathrm{~Hz}\right), 7.42\left(2 \mathrm{H}, \mathrm{m}, \mathrm{C}_{6} \mathrm{H}_{4}\right), 7.52(1 \mathrm{H}$, dd, $\left.\mathrm{C}_{6} \mathrm{H}_{4},{ }^{3} J_{\mathrm{HH}} 6.6,{ }^{4} J_{\mathrm{HH}} 2.0 \mathrm{~Hz}\right) .{ }^{13} \mathrm{C}\left\{{ }^{1} \mathrm{H}\right\} \mathrm{NMR}(75.42 \mathrm{MHz}$, $\mathrm{CDCl}_{3}$ ): $\delta 21.13\left(\mathrm{~s}\right.$, para $\left.-\mathrm{CH}_{3}\right), 25.51$ (br s, ortho $-\mathrm{CH}_{3}$ ), 49.45 (br s, $\left.\mathrm{NCH}_{3}\right), 55.10\left(\right.$ br s, $\left.\mathrm{NCH}_{3}\right), 72.09\left(\mathrm{~s}, \mathrm{CH}_{2}\right), 123.54,128.91,130.06$, 130.32, 130.98, 131.12, 133.49, 135.03, 139.67, 141.33, 141.83, 143.88, $144.75\left(\mathrm{C}_{6} \mathrm{H}_{2}, \mathrm{C}_{6} \mathrm{H}_{4}\right)$.

\section{Crystal structures}

The details of the crystal structure determination and refinement are given in Table 3. Block crystals of $\mathbf{1}$ and $\mathbf{2}$ (colourless),

Table 3 Crystallographic data for compounds 1-4

\begin{tabular}{|c|c|c|c|c|}
\hline & 1 & 2 & 3 & 4 \\
\hline Empirical formula & $\mathrm{C}_{15} \mathrm{H}_{17} \mathrm{ClNSb}$ & $\mathrm{C}_{27} \mathrm{H}_{34} \mathrm{NSb}$ & $\mathrm{C}_{15} \mathrm{H}_{17} \mathrm{Cl}_{4} \mathrm{NPdSb} \cdot \mathrm{C}_{9} \mathrm{H}_{14} \mathrm{~N}$ & $\mathrm{C}_{27} \mathrm{H}_{34} \mathrm{Cl}_{2} \mathrm{NPdSb}$ \\
\hline$M$ & 368.50 & 494.30 & 717.46 & 671.60 \\
\hline Crystal system & Monoclinic & Monoclinic & Triclinic & Monoclinic \\
\hline Space group & $P 2_{1} / n$ & $P 2_{1} / c$ & $P \overline{1}$ & $P 2_{1} / n$ \\
\hline$a / \AA$ & $11.630(3)$ & $8.8686(6)$ & $8.7797(9)$ & $9.3725(7)$ \\
\hline$\alpha /^{\circ}$ & 90 & 90 & $98.954(2)$ & 90 \\
\hline$\beta /^{\circ}$ & $99.008(4)$ & $97.9370(10)$ & $102.050(2)$ & $107.6790(10)$ \\
\hline$\gamma /{ }^{\circ}$ & 90 & 90 & $96.987(2)$ & 90 \\
\hline$V / \AA^{3}$ & $1519.5(6)$ & $2467.1(3)$ & $1380.7(3)$ & $2669.4(4)$ \\
\hline$Z$ & 4 & 4 & 2 & 4 \\
\hline No. of reflections collected & 11923 & 19580 & 13150 & 19169 \\
\hline $\mathrm{w} R_{2}$ & 0.0607 & 0.1012 & 0.1129 & 0.0818 \\
\hline GOF on $F_{2}$ & 1.046 & 1.174 & 1.249 & 1.137 \\
\hline
\end{tabular}


3 (brown) and 4 (yellow) were mounted on cryoloops. Data collection and processing were carried out using a Bruker SMART APEX system using graphite-monochromated Mo-K $\alpha$ radiation $(\lambda=0.71073)$ at room temperature $(297 \mathrm{~K})$. The structures were refined with anisotropic thermal parameters. The hydrogen atom attached to nitrogen in the cation of 3 was located from the difference map. The other hydrogen atoms were refined with a riding model and a mutual isotropic thermal parameter. For structure solving and refinement the software package SHELX-97 was used. ${ }^{34}$ The drawings were created with the DIAMOND program..$^{35} \dagger$

\section{Computational details}

Theoretical calculations on 1, 2, the anion and cation of 3, 4, isomers of 1, 2 and 4 were carried out with the ORCA 3.0, software package. ${ }^{37}$ For both the geometry optimizations and frequency calculations the BP86 functional was employed with the dispersion corrections of Grimme and using ZORA approximation. ${ }^{38-40}$ For the $\mathrm{H}$ and $\mathrm{C}$ atoms the def2-SVP-ZORA basis set was used, whereas for N, Cl, Sb and Pd it was used def2TZVP-ZORA basis set. ${ }^{41}$ The energy calculations were performed with the Grid 6 option. The energy minima of the calculated structures were confirmed by the frequency calculations. For the calculation of atomic orbital contributions NBO version 5.9 was used. ${ }^{42}$ The input files for NBO were obtained from single point calculations carried out with ORCA 3.0.1 on the optimized geometries, but without the use of ZORA approximation. For these calculations the Ahlrichs basis sets were used as previously described. ${ }^{43-45}$ The overlaying of the calculated and determined structures was carried out using PyMol. ${ }^{46}$ In the ESI, Fig. S9-S12 $\dagger$ the $\mathrm{Sb}$ atoms were placed in the centre of the coordinates system.

\section{Acknowledgements}

Financial support from the National University Research Council (CNCSIS, Romania; Research Project no. PNII-ID 2052/ 2009) and National Research Council of Romania (CNCS, Research Project no. PN-II-ID-PCE-2011-3-0933) is greatly appreciated. D.C. acknowledges a mobility fellowship CEEX 19/ 2006 for providing research facilities and financial support during a two and a half-months research stay at Dipartimento di Chimica Inorganica ed Analitica, Università degli Studi di Cagliari, Cagliari, Italy. We thank the National Centre for X-Ray Diffraction (Babeş-Bolyai University, Cluj-Napoca) for support of the single crystal X-ray diffraction studies.

\section{Notes and references}

1 H. Breunig, E. Lork, C. Rat and R. Wagner, J. Organomet. Chem., 2007, 692, 3430.

2 V. Sharutin, V. Senchurin, A. Pakusina, O. Sharutina and B. Kunkurdonova, Russ. J. Gen. Chem., 2010, 80, 1753.

3 M. D. Brown, W. Levason, G. Reid and M. Webster, Dalton Trans., 2006, 4039.
4 R. D. Adams, B. Captain and W. C. Pearl Jr, J. Organomet. Chem., 2008, 693, 1636.

5 R. D. Adams and W. C. Pearl, Organometallics, 2010, 29, 3887.

6 W. Levason and G. Reid, Coord. Chem. Rev., 2006, 250, 2565.

7 J. Burt, W. Levason and G. Reid, Coord. Chem. Rev., 2014, 260, 65.

8 V. R. Bojan, E. J. Fernandez, A. Laguna, J. M. Lopez-de Luzuriaga, M. Monge, M. E. Olmos, R. C. Puelles and C. Silvestru, Inorg. Chem., 2010, 49, 5530.

9 L. M. Opris, A. Silvestru, C. Silvestru, H. J. Breunig and E. Lork, Dalton Trans., 2004, 3575.

10 W. Levason, M. L. Matthews, G. Reid and M. Webster, Dalton Trans., 2004, 51.

11 W. Levason, M. L. Matthews, G. Reid and M. Webster, Dalton Trans., 2004, 554.

12 S. L. Benjamin, L. Karagiannidis, W. Levason, G. Reid and M. C. Rogers, Organometallics, 2011, 30, 895.

13 S. L. Benjamin, W. Levason and G. Reid, Organometallics, 2013, 32, 2760.

14 S. Yasuike, Y. Kishi, S.-i. Kawara, K. Yamaguchi and J. Kurita, J. Organomet. Chem., 2006, 691, 2213.

15 S. Okajima, S. Yasuike, N. Kakusawa, A. Osada, K. Yamaguchi, H. Seki and J. Kurita, J. Organomet. Chem., 2002, 656, 234.

16 S. Yasuike, S. Okajima, K. Yamaguchi, H. Seki and J. Kurita, Tetrahedron: Asymmetry, 2000, 11, 4043.

17 J. Kurita, F. Usuda, S. Yasuike, T. Tsuchiya, Y. Tsuda, F. Kiuchi and S. Hosoi, Chem. Commun., 2000, 191.

18 P. P. Phadnis, V. K. Jain and B. Varghese, Appl. Organomet. Chem., 2002, 16, 61.

19 A. Mentes and J. Fawcett, Inorg. Chim. Acta, 2005, 358, 1279.

20 M. Mathew, G. J. Palenik and C. A. McAuliffe, Acta Crystallogr., Sect. C: Cryst. Struct. Commun., 1987, 43, 21.

21 A. Mentes, R. D. W. Kemmitt, J. Fawcett and D. R. Russell, J. Organomet. Chem., 1997, 528, 59.

22 A. Mentes, R. D. W. Kemmitt, J. Fawcett and D. R. Russell, J. Mol. Struct., 2004, 693, 241.

23 A. F. Chiffey, J. Evans, W. Levason and M. Webster, Organometallics, 1995, 14, 1522.

24 S. Yasuike, S. Okajima, K. Yamaguchi, H. Seki and J. Kurita, Tetrahedron, 2003, 59, 4959.

25 D. Copolovici, V. R. Bojan, C. I. Rat, A. Silvestru, H. J. Breunig and C. Silvestru, Dalton Trans., 2010, 39, 6410.

26 Nomenclature of Inorganic Chemistry: IUPAC Recommendations 2005, ed. N. G. Connelly, T. Damhus, R. M. Hartshorn and A. T. Hutton, RSC Publishing, Cambridge, 2005.

27 C. I. Rat, C. Silvestru and H. J. Breunig, Coord. Chem. Rev., 2013, 257, 818.

28 J. Emsley, Die Elemente, Walter de Gruyter, Berlin, 1994.

29 C. J. Carmalt, A. H. Cowley, R. D. Culp, R. A. Jones, S. Kamepalli and N. C. Norman, Inorg. Chem., 1997, 36, 2770.

30 G. Becker, O. Mundt, M. Sachs, H. J. Breunig, E. Lork, J. Probst and A. Silvestru, Z. Anorg. Allg. Chem., 2001, 627, 699.

31 H. J. Breunig and I. Ghesner, Adv. Organomet. Chem., 2003, 49, 95. 
32 M. Nishio, Phys. Chem. Chem. Phys., 2011, 13, 13873.

33 A. Mentes and O. Buyukgungor, Acta Crystallogr., Sect. E: Struct. Rep. Online, 2004, 60, m601.

34 G. M. Sheldrick, Acta Crystallogr., Sect. A: Found. Crystallogr., 2008, 64, 112.

35 DIAMOND-Visual Crystal Structure Information System, Crystal Impact, Postfach 1251, D-53002 Bonn, Germany, 2001.

36 G. M. Sheldrick, SADABS, Program for area detector adsorption correction, Institute for Inorganic Chemistry, University of Göttingen, Germany, 1996.

37 F. Neese, WIREs Comput Mol Sci, 2012, 2, 73.

38 A. D. Becke, Phys. Rev. A: At., Mol., Opt. Phys., 1988, 38, 3098.

39 C. Lee, W. Yang and R. G. Parr, Phys. Rev. B: Condens. Matter Mater. Phys., 1988, 37, 785.

40 S. Grimme, J. Antony, S. Ehrlich and H. Krieg, J. Chem. Phys., 2010, 132, 154104.
41 D. A. Pantazis, X.-Y. Chen, C. R. Landis and F. Neese, J. Chem. Theory Comput., 2008, 4, 908.

42 E. D. Glendening, J. K. Badenhoop, A. E. Reed, J. E. Carpenter, J. A. Bohmann, C. M. Morales and F. Weinhold, NBO, Version 5.9, Theoretical Chemistry Institute, University of Wisconsin, Madison, WI, 2012.

43 A. Schaefer, H. Horn and R. Ahlrichs, J. Chem. Phys., 1992, 97, 2571.

44 A. Schaefer, C. Huber and R. Ahlrichs, J. Chem. Phys., 1994, 100, 5829.

45 F. Weigend and R. Ahlrichs, Phys. Chem. Chem. Phys., 2005, 7, 3297.

46 The PyMOL molecular graphics system, Version 1.6, Schroedinger L L C, Cambridge, MA, 2010. 